\title{
Removing Antibiotic-Resistant Bacteria (ARB) Carrying Genes (ARGs): Challenges and Future Trends
}

\author{
Djamel Ghernaout ${ }^{1,2 *}$, Noureddine Elboughdiri ${ }^{1,3}$ \\ ${ }^{1}$ Chemical Engineering Department, College of Engineering, University of Ha'il, Ha'il, KSA \\ ${ }^{2}$ Chemical Engineering Department, Faculty of Engineering, University of Blida, Blida, Algeria \\ ${ }^{3}$ Département de Génie Chimique de Procédés, Laboratoire Modélisation, Analyse, et Commande des systèmes, Ecole Nationale \\ d’Ingénieurs de Gabès (ENIG), Rue Omar Ibn-Elkhattab, Gabès, Tunisia \\ Email: *djamel_andalus@hotmail.com
}

How to cite this paper: Ghernaout, D. and Elboughdiri, N. (2020) Removing AntibioticResistant Bacteria (ARB) Carrying Genes (ARGs): Challenges and Future Trends. Open Access Library Journal, 7: e6003. https://doi.org/10.4236/oalib.1106003

Received: December 6, 2019

Accepted: January 6, 2020

Published: January 9, 2020

Copyright $\odot 2020$ by author(s) and Open Access Library Inc.

This work is licensed under the Creative Commons Attribution International License (CC BY 4.0).

http://creativecommons.org/licenses/by/4.0/ (c) (i) Open Access

\begin{abstract}
Developed control of chemical disinfection techniques is beginning to be progressively significant in order to equilibrate under-treatment (minimal pathogen demobilization) and over-treatment (immoderate consumption of disinfectant and disinfection by-products generation) that way giving great ecological and economic advantages. This work reviews the most recent and pertinent researches in this field of eliminating Antibiotic-resistant Bacteria (ARB) carrying genes (ARGs) during wastewater treatment especially disinfection. Traditional disinfection techniques may not be efficient in demobilizing $A R B$ and the simultaneous liberation of $A R B$ and antibiotics at sub-lethal concentrations into municipal wastewater treatment plant effluent may promote the development of resistance among bacteria in receiving water. The pathway of the influences of diverse disinfection techniques in water and wastewater (chlorination, UV irradiation, Fenton reaction, ozonation, and photocatalytic oxidation) deserves more attention. The impacts of constructed wetlands and nanotechnology on ARB and ARG have to be more explored. As the best available technology, membranes processes should be widely adopted through the world for removing ARB and ARGs from the perspective of reusing treated wastewater as drinking water. These safe barriers against pollutants diffusion in nature merit more technical and economic expansion for their larger industrial application especially in developing countries.
\end{abstract}

\section{Subject Areas}

Bioengineering, Biotechnology, Microbiology 


\section{Keywords}

Antibiotic-Resistant Bacteria (ARB), Antibiotic Resistance Genes (ARGs), Wastewater Treatment, Disinfection, Oxidation, Escherichia coli

\section{Introduction}

The excess of antibiotic resistance is a worldwide problem for human and animal health. This is due to the fact that this resistance decreases the performance of antibiotics and the treatability of infectious diseases [1] [2]. Antibiotics may choose antibiotic-resistant bacteria (ARB) carrying genes (ARGs) responsible for antibiotic-resistance routes [3] [4] [5]. Employing antibiotics may unavoidably stimulate ARB; however, the misusing or overusing antibiotics is linked to the prevalence of ARB in clinical and animal agriculture domains [3] [6]. There has been mounting worry concerning the existence of ARB and their resistance genes in aquatic mediums, since antibiotic resistance may be spread through splitting ARGs between bacterial communities [7] [8]. Mobile genetic elements, like plasmids, integrons, and transposons, are implicated in ARG splitting via horizontal gene transfer (HGT) phenomena, like conjugation (cell-to-cell contact), transduction (virus-mediated), and transformation (the uptake of exogenous genetic materials) [3]. Taking into account the HGT routes, in both free form (extracellular) and within host cells (intracellular), ARGs are seen to be pollutants of worry in natural and engineered water systems [7] [8] [9].

Urban wastewaters are established as one of the main origins of ARB and ARGs in aquatic mediums [10] [11]. Traditional biological wastewater treatments are unable to completely remove the ARB and ARGs [11] [12], and can even conduct selective elevations of multi-resistant bacterial species [13]. Disinfecting wastewater effluent using chlorine or UV irradiation has been largely exercised to save the microbiological quality of potable water sources and sensitive receiving waters [14] [15] [16] [17] [18]. Improved wastewater treatment employing ozone or $\mathrm{UV} / \mathrm{H}_{2} \mathrm{O}_{2}$ has as well obtained elevating interest in several developed nations and has been applied in numerous nations to remove diverse trace organic pollutants [19]-[25] exercising opposite environmental influences, like hormones and pharmaceuticals [26]. Under such conditions, there has been rising attention in the performance of employing traditional and advanced wastewater disinfection techniques as obstacles versus antibiotic-resistance spreading via diminishing the quantities of ARB and ARGs [1] [27]-[33].

Disinfection (oxidation) techniques, like chlorine, ozone, UV, and $\mathrm{UV} / \mathrm{H}_{2} \mathrm{O}_{2}$, have been tested to demobilize ARB and ARGs in wastewater effluent matrixes in laboratory, pilot, and full-scale investigations [9] [12] [34]-[44]. Generally, wastewater disinfection techniques below usual treatment circumstances may importantly diminish global ARB amounts (frequently by more than several logs); however, at the same time conducting to ARB selection (i.e., an augmenta- 
tion of the relative proportions of ARB amongst the surviving bacterial cells) [34] [38] [45] [46]. This makes more difficult the evaluation of disinfection's performance in diminishing the capacity of antibiotic-resistance spreading [47] [48] [49] [50]. Diminishing ARG quantities, which was assessed by the quantitative polymerase chain reaction ( $\mathrm{qPCR}$ ) technique, was frequently much less important contrasted to that of ARB, showing the more resistant quality of DNA versus bacterial cells themselves. In general, wastewater disinfection techniques have to be accurately estimated and then regulated to attain enough degrees of ARG demobilization [1].

The demobilization performance of ARGs throughout wastewater disinfection is a function of diverse parameters [51]. Primarily, the kind of ARGs is fundamental. If ARGs are existing within extracellular or intracellular DNA (from now on designated as e-ARG and i-ARG), they can influence the efficiency of ARG deterioration by oxidants or UV [9]. The influence of ARG kind on its demobilization performance by diverse disinfection techniques is deficiently established. Secondly, varying levels of ARG demobilization may be quantified following which analytical techniques are employed. Lately, qPCR-based techniques have been largely used to measure ARG deterioration. Most former investigations employed the qPCR technique optimized for short amplicons (e.g., 100 - $200 \mathrm{bp}$ ). Nevertheless, the short amplicon-based qPCR techniques may undervalue ARG demolition and related absence of ARG biological role [39] [52] [53]. Thirdly, the running circumstances of disinfection technologies (such as oxidant or UV injection) and water characteristics (like dissolved organic matter [54]-[60]) may greatly touch ARG demobilization degrees. Most past researches were performed below the particular situations formed by disinfection technologies and wastewater matrixes, which shortens possibilities for inter-comparison and generalization of the finds. In this regard, it is advised to define principle-based kinetic parameters for ARG demobilization in clean water matrixes (such as no oxidant demand). At most, few investigations have accurately defined commonly viable rate constants for ARG demobilization, like for ozonation [35] and UV disinfection [39] [52]. To conclude, regardless of huge modern research advance, it remains hard to foresee the demobilization degrees of varying sorts of ARGs throughout wastewater disinfection or oxidation at a changing running technique or water matrix situations [1].

This work reviews the most recent and pertinent researches in this field of eliminating ARB and ARG through wastewater treatment.

\section{Demobilization of Plasmid-Encoded Antibiotic Resistance Genes Using Chlorine, UV, and $\mathrm{UV} / \mathrm{H}_{2} \mathrm{O}_{2}$}

Yoon et al. [1] evaluated the demobilization efficacy of plasmid-encoded antibiotic resistance genes (ARGs) both in extracellular form (e-ARG) and existing inside Escherichia coli (E. coli) (intracellular form, i-ARG) throughout water treatment [61] [62] [63] [64] [65] using chlorine, $\mathrm{UV}$ (254 nm), and $\mathrm{UV} / \mathrm{H}_{2} \mathrm{O}_{2}$. 
They employed a quantitative real-time PCR (qPCR) technique to measure the ARG demolition to $a m p^{R}(850 \mathrm{bp})$ and $\operatorname{kan}^{R}$ (806 bp) amplicons, both of which are located in the pUC4K plasmid. The plate count and flow cytometry techniques were as well utilized to control the bacterial demobilization factors, like cultivability and membrane deterioration [66], respectively. They measured the kinetics of $E$. coli [67] demobilization and ARG demolition in phosphate-buffered solutions. The ARG demolition took place much more tardily than $E$. coli demobilization in all situations. To attain 4-log lowering of ARG concentration at $\mathrm{pH} 7$, the needed chlorine subjection and UV fluence were $33-72(\mathrm{mg} \times \mathrm{min}) / \mathrm{L}$ for chlorine and $50-130 \mathrm{~mJ} / \mathrm{cm}^{2}$ for $\mathrm{UV}$ and $\mathrm{UV} / \mathrm{H}_{2} \mathrm{O}_{2}$. After augmenting $\mathrm{pH}$ from 7 to 8, the averages of ARG demolition diminished for chlorine; however, they did not change for UV and $\mathrm{UV} / \mathrm{H}_{2} \mathrm{O}_{2}$. The i-ARGs generally depicted lower averages of deterioration contrasted to the e-ARGs because of the preservative functions of cellular components versus oxidants and UV. The participation of - $\mathrm{OH}$ radicals [68] [69] to i-ARG demolition was modest in $\mathrm{UV} / \mathrm{H}_{2} \mathrm{O}_{2}$ because of important ${ }^{\bullet} \mathrm{OH}$ radical scavenging via cellular components. In all situations, the ARG demolition averages were identical for $a m p^{R}$ against $k a n^{R}$, except for the chlorination of e-ARGs, in which the deterioration to $a m p^{R}$ took place faster than that to $\operatorname{kan}^{R}$. Chlorine and UV dose-dependent ARG demobilization degrees evaluated in a wastewater effluent matrix could be rationally interpreted using the kinetic data gained from the phosphate-buffered solutions and the predictable oxidant (chlorine and ${ }^{\bullet} \mathrm{OH}$ radicals) demands by water matrix components. These findings may be helpful in regulating chlorine and UV-based disinfection setups to obtain ARG demobilization [1].

Rizzo et al. [70] compared the impact of UV radiation on antibiotic-resistant E. coli strains with that of chlorination method. Below the tried circumstances, UV disinfection technique conducted to a completed emobilization following $60 \mathrm{~min}$ of irradiation $\left(1.25 \times 10^{4} \mu \mathrm{Ws} / \mathrm{cm}^{2}\right)$ contrasted to $120 \mathrm{~min}$ chlorine residence period (initial chlorine dose of $2 \mathrm{mg} / \mathrm{L}$ ). Further, no modification in E. coli strains' resistance to amoxicillin (AMX) (minimum inhibiting concentration (MIC) $>256 \mathrm{mg} / \mathrm{L}$ ) and sulfamethoxazole (SMZ) (MIC > $1024 \mathrm{mg} / \mathrm{L}$ ) could be found following UV application. At the same time, the treatment touched resistance of the lower resistance strain to ciprofloxacin (CPX) (MIC diminished by $33 \%$ and $50 \%$ following 60 and $120 \mathrm{~min}$, respectively). Contrarily, chlorination method did not influence antibiotic resistance of the tested $E$. coli strains. Finally, the impact of UV radiation on the mixture of three antibiotics was also examined and photodegradation data fit quite well pseudo first order kinetic models with $t_{1 / 2}$ values of 14, 20 and $25 \mathrm{~min}$ for CPX, AMX and SMZ, respectively. Following these findings, classical disinfection techniques may not be efficient in demobilizing ARB, and the simultaneous liberation of $A R B$ and antibiotics at sub-lethal concentrations into municipal WWTP effluent may promote the development of resistance among bacteria in receiving water. 


\section{Contribution of Full-Scale Wastewater Treatment Plants on Antibiotic Resistant Bacteria Environmental Spreading}

Turolla et al. [71] studied the existence of antibiotic-resistant bacteria (ARB) in wastewater and focused on the contribution of the wastewater treatment plants (WWTPs) in raising or restricting antibiotic resistance. They controlled E. coli and total heterotrophic bacteria (THB) resistance to ampicillin, chloramphenicol, and tetracycline in three WWTPs situated in Milan (Italy), varying between them for the running factors of biological technology, for the disinfection techniques (founded on sodium hypochlorite, UV radiation, peracetic acid (PAA) [72]) and for the discharge limits to be satisfied. They gathered wastewater from three sampling points over the treatment succession (WWTP influent, effluent from sand filtration, WWTP effluent). Antibiotic resistance to ampicillin was detected both for $E$. coli and for THB. Ampicillin resistant bacteria in the WWTP influents were $20 \%-47 \%$ of $E$. coli and $16 \%-25 \%$ of THB counts [71]. Restricted resistance to chloramphenicol was found only for $E$. coli; however, neither for $E$. coli nor for THB tetracycline resistance was noted. The biological treatment and sand filtration conducted to a diminution in the maximum percentage of ampicillin-resistant bacteria (20\% - 29\% for E. coli, $11 \%-21 \%$ for THB). Nevertheless, the usually followed factors did not appear convenient to boost an explication of WWTP contribution in ARB diffusion. PAA was efficient in selectively performing on antibiotic-resistant THB, in contrast to UV radiation and sodium hypochlorite [71].

PAA is an organic chemical employed efficaciously as a disinfectant in wastewater treatments. So far, at minimum injections it may provoke selection; therefore, Turolla et al. [73] assessed the impact of minimum injections of PAA on Enterococcus faecium as a proxy of human-related microbial waste (Figure 1). They treated bacteria using elevating injections of PAA (from 0 to $25 \mathrm{mg} / \mathrm{L} \mathrm{min}$ ) and incubated in regrowth tests below non-growing, restricting circumstances and below growing, appropriate situations. The modifications in bacterial plenty, in bacterial phenotype (number and composition of small cell clusters), and in the plenty of an ARG were estimated. The trials established that the chosen injections of PAA efficaciously eliminated enterococci, and generated a long-lasting influence following PAA demobilization. The comparative plenty of small clusters augmented throughout the test if contrasted with that of the inoculum. Further, below growing suitable situations, the comparative plenty of small clusters diminished and the number of cells per cluster augmented with elevating PAA injections. Robust constancy of the evaluated ARG was observed, not depicting any influence throughout the full test. The findings established the likelihood of small injections of PAA to demobilize bacteria. Nevertheless, the stress formed by PAA disinfection encouraged a bacterial adaptation, even if potentially without touching the plenty of the ARG.

Manoli et al. [74] offered the development, verification, and pilot-scale validation of a new CT-based real-time disinfection control procedure, derived from 
first principles and implemented to PAA disinfection of domestic secondary effluent wastewater. They performed validation tests employing a $3-\mathrm{m}^{3}$ pilot contact basin of which the hydraulic efficacy was first characterized by means of tracer trials and then mathematically modeled employing the well-established theoretical framework of continuous stirred-tank reactors in series (Figure 2). The analytical model defining hydraulic efficacy was then expanded to consider disinfectant demand/decay and microbial demobilization kinetics. The integrated model was successfully employed to foresee, and control, residual PAA as well as microbial concentration in the pilot effluent. Validation investigations once and for all backed that the new CT-based control procedure was superior in keeping constant disinfection efficiency, wanted microbial counts, and low residual disinfectant under variable flow and wastewater quality. If compared with flow pacing, the CT-based control needed two times less the quantity of chemical for the identical treatment target $(<100 \mathrm{CFU} / 100 \mathrm{~mL})$. Outstandingly, the

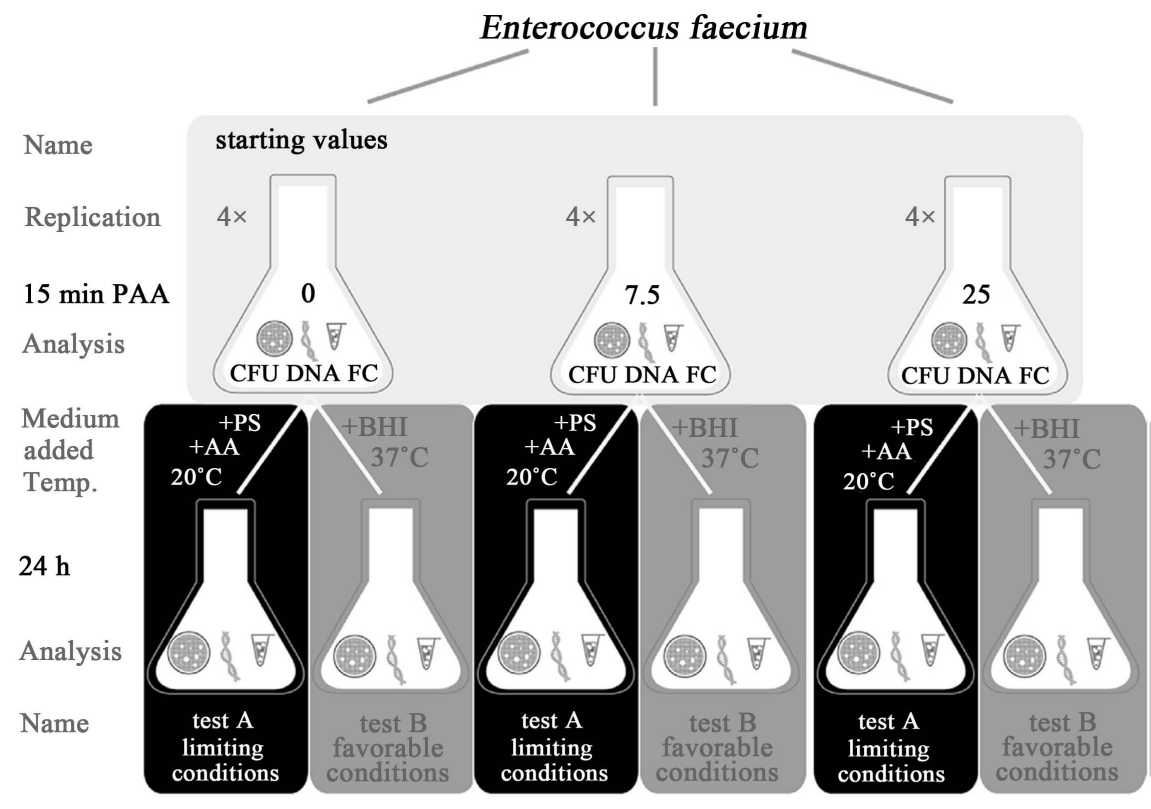

CFU - colony forming unit I DNA - extracion for qPCR I F FC - flow cytometry

Figure 1. Graphical depiction of the experimental design (disinfection treatments and regrowth tests under limiting (test A) and favorable conditions (test B)). Abbreviations: $\mathrm{BHI}$, brain-hearth infusion broth; CFU, colony forming units; DNA, extraction for qPCR; FC, flow cytometry; PAA, Peracetic Acid; PS, physiological solution [73].

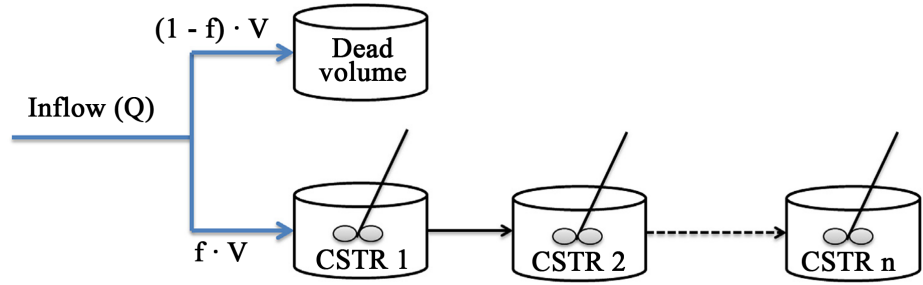

Figure 2. Conceptual representation of the n-CSTRs model modified by the addition of an effective volume factor (f) [74]. 
CT-based control procedure may be widespread to diverse chemical disinfection techniques like chlorination and ozonation, solo or in integration with physical treatment methods like membranes [75] [76] [77] [78] and UV irradiation.

Researchers [79] presented an overview of the present understanding about demobilization of ARB and ARG (Figure 3). They also focused on the pathway of the influences of diverse disinfection techniques in water and wastewater (chlorination, UV irradiation, Fenton reaction, ozonation, and photocatalytic oxidation) (Figure 4). They also discussed the impacts of constructed wetlands (CWs) and nanotechnology [80] on ARB and ARG (Figure 5).

McConnell et al. [82] tried to answer the question how single treatment stages in two tertiary WWTPs influenced the elimination (copies $/ \mathrm{mL}$ ) and relative plenty of ARGs (copies/copies 16S rRNA genes). Nine ARG markers, exemplifying resistance to frequently employed antibiotics, as well as one integron gene (int 1 ) to evaluate ARG mobility capacity, were measured utilizing quantitative real-time PCR (qPCR). Both WWTPs satisfied provincial effluent regulations for the elimination of carbonaceous oxygen demand $\left(\mathrm{CBOD}_{5}\right)$ and total suspended solids. Eight of the ten ARG markers (intl1, sull, suh, tet(O), ermB, bla $a_{\text {Стх-м }}$, $\left.b l a_{\mathrm{TEM}}, q n r S\right)$ were found in all samples. At the opposite, mecA was observed intermittently and vanA stayed under the detection limit in all samples. The total ARG marker plenties diminished by $\log 1.77$ ( $\mathrm{p} \mathrm{b} 0.05$ ) in the WWTP employing an aerated lagoon (AL), and by $2.69 \operatorname{logs}(\mathrm{p} \mathrm{b} 0.05$ ) via treatment in the plant utilizing a biological nutrient removal (BNR) system. The BNR and secondary clarifier stages in both WWTPs afforded the most elimination of ARGs. The comparative plenty of ARGs stayed unaltered at the AL plant and depicted a diminishing tendency at the BNR plant (Figure 6). Degrees of CBOD5, nitrate and the human Bacteroides fecal marker matched with ARG concentrations, proposing such variables may be helpful in divining ARG reduction. Finally, the effluent coming from the WWTPs comprised eight of the followed ARG markers in concentrations varying from 0.01 to $3.6 \log$ copies/mL, illustrating their liberation into nature; nevertheless, the comparative plenty of ARGs was not reinforced throughout treatment in the two WWTPs.

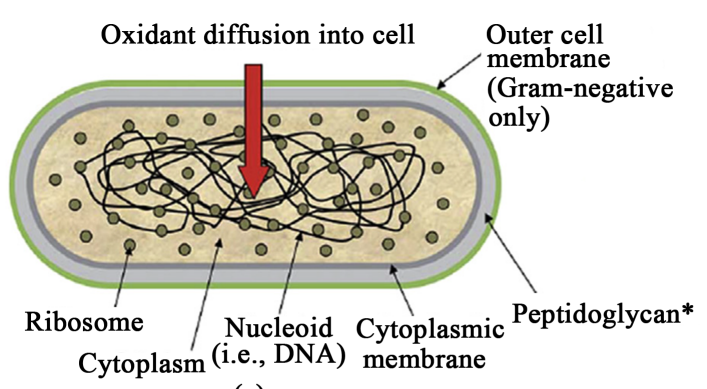

(a)

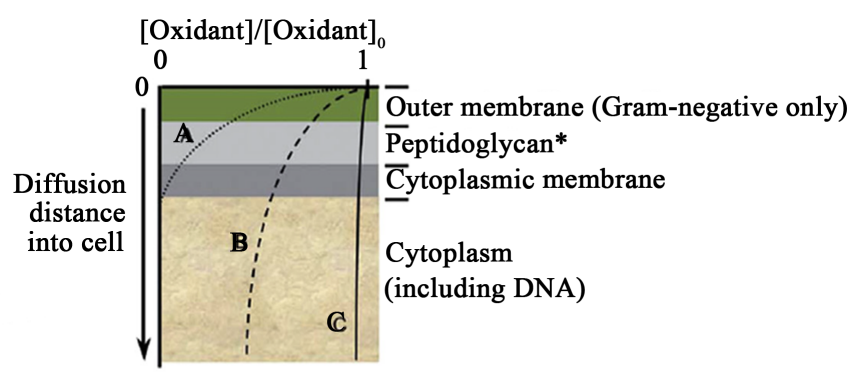

(b)

*Gram-positive cells have a thick peptidoglycan layer, while Gram-negative cells have a thin peptidoglycan layer surrounded by protein-rich periplasm.

Figure 3. Overview of (a) a generic vegetative bacterial cell, and (b) variations in concentrations of several hypothetical oxidants with increasing diffusion distance into the cell (where " $A$ " represents an oxidant with high reactivity toward cell envelope constituents, " $B$ " represents an oxidant with moderate reactivity toward cell envelope constituents and DNA, and " $C$ ” represents an oxidant with low reactivity toward all cell constituents) [9] [79]. 


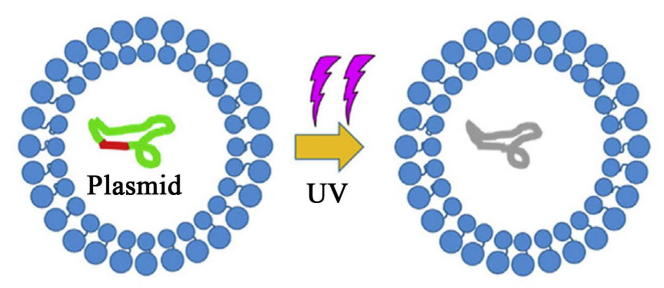

(a)
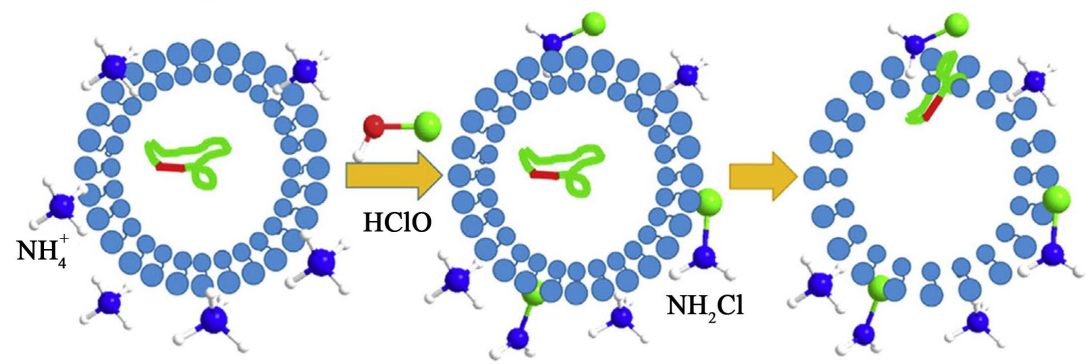

(b)

Figure 4. Comparison of the mechanisms of UV disinfection (a) and chlorination (b) affecting the ARGs conjugation transfer [79] [81].

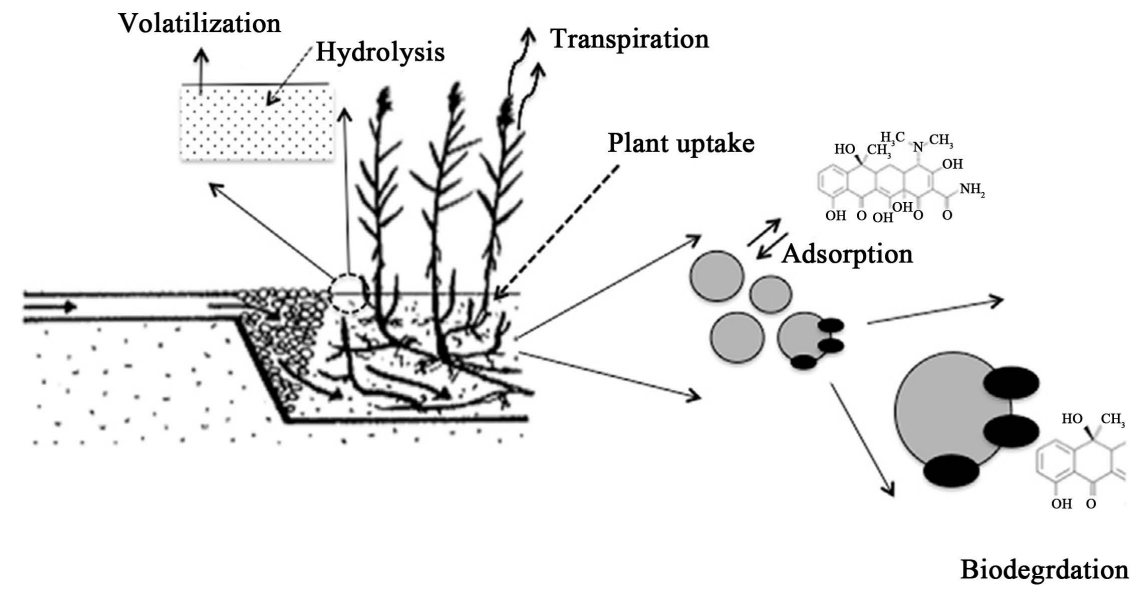

Figure 5. Major mechanisms of pharmaceutical removal in a constructed wetland (CW) $[79]$.

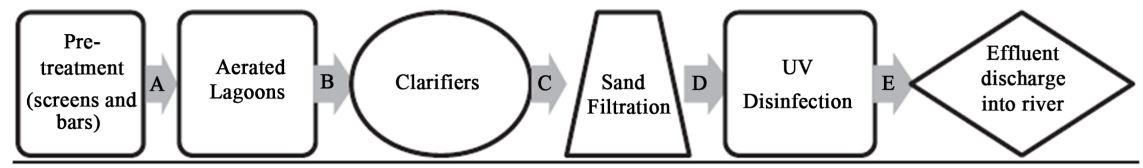

(a)

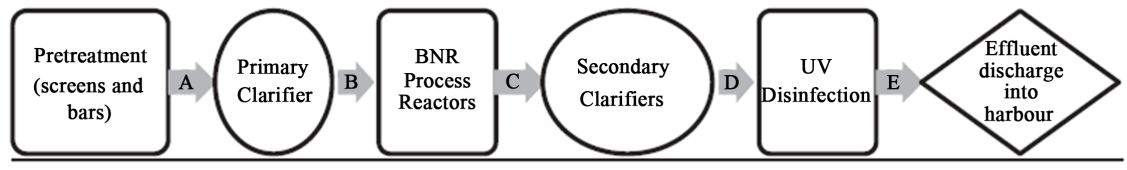

(b)

Figure 6. Schematic layout of the treatment trains of (a) the aerated lagoon (AL) plant and (b) the biological nutrient removal (BNR) plant with sampling sites indicated by letters (A - E) [82]. (a) AL plant; (b) BNR plant. 


\section{Conclusions}

The main points drawn from this work may be given as:

1) Numerous investigations have illustrated the spread of ARB and ARG in WWTP effluents, sludge, biosolids, urban solid waste leachates, soils, rivers, lakes, and surface water of livestock farms of diverse areas of the world. The discovery of ARG comprises sulfonamide, tetracycline, beta-lactam, and fluoroquinolone resistance genes. There is a shortage of details regarding the plenty and behavior of ARB and ARG, mostly in WWTPs. Moreover, a more explained comprehension of resistance pathways and their diffusion would help in conveniently evaluating the hazard related to ARB and ARG to public health and ecosystems [79].

2) Researches on the demobilization of $A R G$ via disinfection techniques in real drinking water and WWTPs are so restricted. Chemical disinfectants comprising chlorine, ozone, and Fenton reagent, have been shown efficient in demobilizing ARB and ARG. Various log units of demobilization performance were attained, which changed with the injections of the oxidants. The demobilization degrees of chosen ARG were 1.65 - 2.2, 0.60, and 2.42 - 3.38 log units for chlorination, ozonation, and Fenton oxidation, respectively. Nevertheless, much more investigation is necessitated to enhance the comprehension of the removal of ARG from treated water employing chemical disinfection techniques, especially chlorination which is largely employed all over the world. Restricted research on the usage of UV irradiation to demobilize ARB and ARG has shown its performance; however, a small UV injection was not able in diminishing the frequency of conjugative transfer. More important, an elevated UV injection was hardly fit to diminish the frequency of conjugative transfer. Photocatalytical methods employing $\mathrm{TiO}_{2}$ have depicted performance in demobilizing ARB and ARG; however, the necessitated treatment has to be for a prolonged residence time (hundreds of $\mathrm{min}$ ). Improving photocatalysts below visible light may ameliorate the performance of photocatalytical remediation [79].

3) Thanks to the environmentally-friendly type of the CWs, several types of research are dedicated to exploring their aptness for eliminating antibiotics from wastewater. Physicochemical routes implied in eliminating antibiotics flowing in a CW are in fact well authenticated. Nevertheless, it has not been deeply studied what microorganisms are in charge of the antibiotic elimination in a CW. Furthermore, the manner in which ARGs are grown or decreased in a CW has not been enough examined. In fact, the running circumstances below which ARGs are grown or decreased should be more examined. Especially, the connection among the flow scheme of a CW and the plenty of ARB or ARG remains to be investigated. Nanoparticles are coming into the wastewater effluent and sludge; however, their impact on the ARB and ARG remains widely obscure. Next investigations have to involve the role of nanomaterials in the route of diffusion of ARG across genera to estimate the viability of ARB and residual copy numbers of ARG [79]. 
4) Water reusing is aligned to broader, international $R \& D$ trends [83] [84]. Indeed, water reusing is applied through all the industrialized countries and several developing nations [85] [86] [87] [88]. Water reusing is the best solution to overcome the pollutants diffusion through nature [89] [90] [91] [92] [93]. Indeed, WWTPs have to be upgraded to treat wastewater at the highest level to reuse it as drinking potable [94] [95] [96].

\section{Conflicts of Interest}

The authors declare no conflicts of interest regarding the publication of this paper.

\section{References}

[1] Yoon, Y., Chung, H.J., Di, D.Y.W., Dodd, M.C., Hur, H.-G. and Lee, Y. (2017) Inactivation Efficiency of Plasmid-Encoded Antibiotic Resistance Genes during Water Treatment with Chlorine, UV, and $\mathrm{UV} / \mathrm{H}_{2} \mathrm{O}_{2}$. Water Research, 123, 783-793. https://doi.org/10.1016/j.watres.2017.06.056

[2] WHO (World Health Organization) (2014) Antimicrobial Resistance: Global Report on Surveillance.

[3] Keen, P.L. and Montforts, M.H.M.M. (2012) Antimicrobial Resistance in the Environment. John Wiley \& Sons, Inc., Hoboken. https://doi.org/10.1002/9781118156247

[4] Makowska, N., Koczura, R. and Mokracka, J. (2016) Class 1 Integrase, Sulfonamide and Tetracycline Resistance Genes in Wastewater Treatment Plant and Surface Water. Chemosphere, 144, 1665-1673. https://doi.org/10.1016/j.chemosphere.2015.10.044

[5] Roca, I., Akova, M., Baquero, F., Carlet, J., Cavaleri, M., Coenen, S., Cohen, J., Findlay, D., Gyssens, I., Heure, O.E., Kahlmeter, G., Kruse, H., Laxminarayan, R., Liébana, E., López-Cerero, L., MacGowan, A., Martins, M., Rodríguez-Baño, J., Rolain, J.-M., Segovia, C., Sigauque, B., Tacconelli, E., Wellington, E. and Vila, J. (2015) The Global Threat of Antimicrobial Resistance: Science for Intervention. New Microbes and New Infections, 6, 22-29. https://doi.org/10.1016/j.nmni.2015.02.007

[6] Luprano, M.L., De Sanctis, M., Del Moro, G., Di Iaconi, C., Lopez, A. and Levantesi, C. (2016) Antibiotic Resistance Genes Fate and Removal by a Technological Treatment Solution for Water Reuse in Agriculture. Science of the Total Environment, 571, 809-818. https://doi.org/10.1016/j.scitotenv.2016.07.055

[7] Berendonk, T., Manaia, C.M., Merlin, C., Fatta-Kassinos, D., Cytryn, E., Walsh, F., Bürgmann, H., Sørum, H., Norström, M., Pons, M.-N., Kreuzinger, N., Huovinen, P., Stefani, S., Schwartz, T., Kisand, V., Baquero, F. and Martinez, J.L. (2015) Tackling Antibiotic Resistance: The Environmental Framework. Nature Reviews Microbiology, 13, 310-317. https://doi.org/10.1038/nrmicro3439

[8] Pruden, A. (2014) Balancing Water Sustainability and Public Health Goals in the Face of Growing Concerns about Antibiotic Resistance. Environmental Science \& Technology, 48, 5-14. https://doi.org/10.1021/es403883p

[9] Dodd, M.C. (2012) Potential Impacts of Disinfection Processes on Elimination and Deactivation of Antibiotic Resistance Genes during Water and Wastewater Treatment. Journal of Environmental Monitoring, 14, 1754-1771. 
https://doi.org/10.1039/c2em00006g

[10] Łuczkiewicz, A., Jankowska, K., Fudala-Książek, S. and Olańczuk-Neyman, K. (2010) Antimicrobial Resistance of Fecal Indicators in Municipal Wastewater Treatment Plant. Water Research, 44, 5089-5097. https://doi.org/10.1016/j.watres.2010.08.007

[11] Rizzo, L., Manaia, C., Merlin, C., Schwartz, T., Dagot, C., Poly, M.C., Michael, I. and Fatta-Kassinos, D. (2013) Urban Wastewater Treatment Plants as Hotspots for Antibiotic Resistant Bacteria and Genes Spread into the Environment: A Review. Science of the Total Environment, 447, 345-360. https://doi.org/10.1016/j.scitotenv.2013.01.032

[12] Chen, H. and Zhang, M. (2013) Effects of Advanced Treatment Systems on the Removal of Antibiotic Resistance Genes in Wastewater Treatment Plants from Hangzhou, China. Environmental Science \& Technology, 47, 8157-8163. https://doi.org/10.1021/es401091y

[13] Czekalski, N., Berthold, T., Caucci, S., Egli, A. and Bürgmann, H. (2012) Increased Levels of Multiresistant Bacteria and Resistance Genes after Wastewater Treatment and Their Dissemination into Lake Geneva, Switzerland. Frontiers in Microbiology, 3, 1-18. https://doi.org/10.3389/fmicb.2012.00106

[14] Ghernaout, D. (2017) Water Treatment Chlorination: An Updated Mechanistic Insight Review. Chemistry Research Journal, 2, 125-138.

[15] Ghernaout, D., Moulay, S., AitMessaoudene, N., Aichouni, M., Naceur, M.W. and Boucherit, A. (2014) Coagulation and Chlorination of NOM and Algae in Water Treatment: A Review. International Journal of Environmental Monitoring and Analysis, 2, 23-34. https://doi.org/10.11648/j.ijema.s.2014020601.14

[16] Ghernaout, D., Laribi, C., Alghamdi, A., Ghernaout, B., AitMessaoudene, N. and Aichouni, M. (2018) Decolorization of BF Cibacete Blue (CB) and Red Solophenyle 3BL (RS) Using Aluminum Sulfate and Ferric Chloride. World Journal of Applied Chemistry, 3, 32-40. https://doi.org/10.11648/j.wjac.20180302.11

[17] Ghernaout, D., Alghamdi, A., Aichouni, M. and Touahmia, M. (2018) The Lethal Water Tri-Therapy: Chlorine, Alum, and Polyelectrolyte. World Journal of Applied Chemistry, 3, 65-71. https://doi.org/10.11648/j.wjac.20180302.14

[18] Jacangelo, J.G. and Trussell, R.R. (2002) International Report: Water and Wastewater Disinfection-Trends, Issues, and Practices. Water Science and Technology: Water Supply, 2, 147-157. https://doi.org/10.2166/ws.2002.0097

[19] Ghernaout, D., Ghernaout, B., Saiba, A., Boucherit, A. and Kellil, A. (2009) Removal of Humic Acids by Continuous Electromagnetic Treatment Followed by Electrocoagulation in Batch Using Aluminium Electrodes. Desalination, 239, 295-308. https://doi.org/10.1016/j.desal.2008.04.001

[20] Ghernaout, D., Ghernaout, B. and Kellil, A. (2009) Natural Organic Matter Removal and Enhanced Coagulation as a Link between Coagulation and Electrocoagulation. Desalination and Water Treatment, 2, 203-222. https://doi.org/10.5004/dwt.2009.116

[21] Ghernaout, D., Ghernaout, B., Boucherit, A., Naceur, M.W., Khelifa, A. and Kellil, A. (2009) Study on Mechanism of Electrocoagulation with Iron Electrodes in Idealised Conditions and Electrocoagulation of Humic Acids Solution in Batch Using Aluminium Electrodes. Desalination and Water Treatment, 8, 91-99. https://doi.org/10.5004/dwt.2009.668

[22] Belhout, D., Ghernaout, D., Djezzar-Douakh, S. and Kellil, A. (2010) Electrocoagulation of a Raw Water of Ghrib Dam (Algeria) in Batch Using Iron Electrodes. De- 
salination and Water Treatment, 16, 1-9. https://doi.org/10.5004/dwt.2010.1081

[23] Ghernaout, D. and Ghernaout, B. (2012) Sweep Flocculation as a Second Form of Charge Neutralisation: A Review. Desalination and Water Treatment, 44, 15-28. https://doi.org/10.1080/19443994.2012.691699

[24] Ghernaout, D. and Ghernaout, B. (2012) On the Concept of the Future Drinking Water Treatment Plant: Algae Harvesting from the Algal Biomass for Biodiesel Production: A Review. Desalination and Water Treatment, 49, 1-18. https://doi.org/10.1080/19443994.2012.708191

[25] Ghernaout, D., Irki, S. and Boucherit, A. (2014) Removal of $\mathrm{Cu}^{2+}$ and $\mathrm{Cd}^{2+}$, and Humic Acid and Phenol by Electrocoagulation Using Iron Electrodes. Desalination and Water Treatment, 52, 3256-3270. https://doi.org/10.1080/19443994.2013.852484

[26] Eggen, R.I.L., Hollender, J., Joss, A., Schärer, M. and Stamm, C. (2014) Reducing the Discharge of Micropollutants in the Aquatic Environment: The Benefits of Upgrading Wastewater Treatment Plants. Environmental Science \& Technology, 48, 7683-7689. https://doi.org/10.1021/es500907n

[27] Ghernaout, D. and Ghernaout, B. (2010) From Chemical Disinfection to Electrodisinfection: The Obligatory Itinerary? Desalination and Water Treatment, 16, 156-175. https://doi.org/10.5004/dwt.2010.1085

[28] Boucherit, A., Moulay, S., Ghernaout, D., Al-Ghonamy, A.I., Ghernaout, B., Naceur, M.W., AitMessaoudene, N., Aichouni, M., Mahjoubi, A.A. and Elboughdiri, N.A. (2015) New Trends in Disinfection By-Products Formation upon Water Treatment. Journal of Research \& Developments in Chemistry, 2015, Article ID: 628833. https://doi.org/10.5171/2015.628833

[29] Ghernaout, D. (2017) Microorganisms' Electrochemical Disinfection Phenomena. EC Microbiology, 9, 160-169.

[30] Ghernaout, D. (2018) Disinfection and DBPs Removal in Drinking Water Treatment: A Perspective for a Green Technology. International Journal of Advanced and Applied Sciences, 5, 108-117. https://doi.org/10.21833/ijaas.2018.02.018

[31] Ghernaout, D., Aichouni, M. and Touahmia, M. (2019) Mechanistic Insight into Disinfection by Electrocoagulation: A Review. Desalination and Water Treatment, 141, 68-81. https://doi.org/10.5004/dwt.2019.23457

[32] Ghernaout, D., Alghamdi, A. and Ghernaout, B. (2019) Microorganisms' Killing: Chemical Disinfection vs. Electrodisinfection. Applied Engineering, 3, 13-19.

[33] Ghernaout, D. (2019) Disinfection via Electrocoagulation Process: Implied Mechanisms and Future Tendencies, EC Microbiology, 15, 79-90.

[34] Alexander, J., Knopp, G., Dötsch, A., Wieland, A. and Schwartz, T. (2016) Ozone Treatment of Conditioned Wastewater Selects Antibiotic Resistance Genes, Opportunistic Bacteria, and Induce Strong Population Shifts. Science of the Total Environment, 559, 103-112. https://doi.org/10.1016/j.scitotenv.2016.03.154

[35] Czekalski, N., Imminger, S., Salhi, E., Veljkovic, M., Kleffel, K., Drissner, D., Hammes, F., Bürgmann, H. and von Gunten, U. (2016) Inactivation of Antibiotic Resistant Bacteria and Resistance Genes by Ozone: From Laboratory Experiments to Full-Scale Wastewater Treatment. Environmental Science \& Technology, 50, 11862-11871. https://doi.org/10.1021/acs.est.6b02640

[36] Ferro, G., Guarino, F., Cicatelli, A. and Rizzo, L. (2017) $\beta$-Lactams Resistance Gene Quantification in an Antibiotic Resistant Escherichia coli Water Suspension Treated by Advanced Oxidation with $\mathrm{UV} / \mathrm{H}_{2} \mathrm{O}_{2}$. Journal of Hazardous Materials, 323, 
426-433. https://doi.org/10.1016/j.jhazmat.2016.03.014

[37] Huang, J.-J., Hu, H.-Y., Wu, Y.-H., Wei, B. and Lu, Y. (2013) Effect of Chlorination and Ultraviolet Disinfection on tetA-Mediated Tetracycline Resistance of Escherichia coli. Chemosphere, 90, 2247-2253.

https://doi.org/10.1016/j.chemosphere.2012.10.008

[38] Lüddeke, F., He, S., Gallert, C., Winter, J., Güde, H. and Löffler, H. (2015) Removal of Total and Antibiotic Resistant Bacteria in Advanced Wastewater Treatment by Ozonation in Combination with Different Filtering Techniques. Water Research, 69, 243-251. https://doi.org/10.1016/j.watres.2014.11.018

[39] McKinney, C.W. and Pruden, A. (2012) Ultraviolet Disinfection of Antibiotic Resistant Bacteria and Their Antibiotic Resistance Genes in Water and Wastewater. Environmental Science \& Technology, 46, 13393-13400. https://doi.org/10.1021/es303652q

[40] Pak, G., Salcedo, D.E., Lee, H., Oh, J., Maeng, S.K., Song, K.G., Hong, S.W., Kim, H.-C., Chandran, K. and Kim, S. (2016) Comparison of Antibiotic Resistance Removal Efficiencies Using Ozone Disinfection under Different $\mathrm{pH}$ and Suspended Solids and Humic Substance Concentrations. Environmental Science \& Technology, 50, 7590-7600. https://doi.org/10.1021/acs.est.6b01340

[41] Sousaa, J.M., Macedob, G., Pedrosac, M., Becerra-Castroa, C., Castro-Silvad, S., Pereirac, M.F.R., Silva, A.M.T., Nunesa, O.C. and Manaia, C.M. (2017) Ozonation and $\mathrm{UV}_{254} \mathrm{~nm}$ Radiation for the Removal of Microorganisms and Antibiotic Resistance Genes from Urban Wastewater. Journal of Hazardous Materials, 323, 434-441. https://doi.org/10.1016/j.jhazmat.2016.03.096

[42] Yuan, Q.-B., Guo, M.-T. and Yang, J. (2015) Fate of Antibiotic Resistant Bacteria and Genes during Wastewater Chlorination: Impact for Antibiotic Resistance Control. PLoS ONE, 10, e119403. https://doi.org/10.1371/journal.pone.0119403

[43] Zhang, Y., Zhuang, Y., Geng, J., Ren, H., Zhang, Y., Ding, L. and Xu, K. (2015) Inactivation of Antibiotic Resistance Genes in Municipal Wastewater Effluent by Chlorination Disinfection-Trends, Issues, and Practices. Environmental Science and Pollution Research, 2, 147-157.

[44] Zhuang, Y., Ren, H., Geng, J., Zhang, Y., Zhang, Y., Ding, L. and Xu, K. (2015) Inactivation of Antibiotic Resistance Genes in Municipal Wastewater by Chlorination, Ultraviolet, and Ozonation Disinfection. Environmental Science and Pollution Research, 22, 7037-7044. https://doi.org/10.1007/s11356-014-3919-z

[45] Ghernaout, D. and Elboughdiri, N. (2019) Mechanistic Insight into Disinfection Using Ferrate (VI). Open Access Library Journal, 6, e5946.

[46] Ghernaout, D. and Elboughdiri, N. (2019) Water Disinfection: Ferrate (VI) as the Greenest Chemical-A Review. Applied Engineering, 3, 171-180.

[47] Ghernaout, D., Touahmia, M. and Aichouni, M. (2019) Disinfecting Water: Electrocoagulation as an Efficient Process. Applied Engineering, 3, 1-12.

[48] Ghernaout, D. (2019) Greening Electrocoagulation Process for Disinfecting Water. Applied Engineering, 3, 27-31.

[49] Ghernaout, D. (2019) Electrocoagulation and Electrooxidation for Disinfecting Water: New Breakthroughs and Implied Mechanisms, Applied Engineering, 3, 125-133.

[50] Ghernaout, D. and Elboughdiri, N. (2019) Electrocoagulation Process Intensification for Disinfecting Water: A Review. Applied Engineering, 3, 140-147.

[51] Ghernaout, D. and Elboughdiri, N. (2019) Iron Electrocoagulation Process for Dis- 
infecting Water: A Review. Applied Engineering, 3, 154-158.

[52] Chang, P.H., Juhrend, B., Olson, T.M., Marrs, C.F. and Wigginton, K.R. (2017) Degradation of Extracellular Antibiotic Resistance Genes with $\mathrm{UV}_{254}$ Treatment. Environmental Science \& Technology, 51, 6185-6192.

https://doi.org/10.1021/acs.est.7b01120

[53] Sü, J., Volz, S., Obst, U. and Schwartz, T. (2009) Application of a Molecular Biology Concept for the Detection of DNA Damage and Repair during UV Disinfection. Water Research, 43, 3705-3716. https://doi.org/10.1016/j.watres.2009.05.048

[54] Ghernaout, B., Ghernaout, D. and Saiba, A. (2010) Algae and Cyanotoxins Removal by Coagulation/Flocculation: A Review. Desalination and Water Treatment, 20, 133-143. https://doi.org/10.5004/dwt.2010.1202

[55] Ghernaout, D., Mariche, A., Ghernaout, B. and Kellil, A. (2010) Electromagnetic Treatment-bi-Electrocoagulation of Humic Acid in Continuous Mode Using Response Surface Method for Its Optimization and Application on Two Surface Waters. Desalination and Water Treatment, 22, 311-329. https://doi.org/10.5004/dwt.2010.1120

[56] Ghernaout, D., Naceur, M.W. and Aouabed, A. (2011) On the Dependence of Chlorine By-Products Generated Species Formation of the Electrode Material and Applied Charge during Electrochemical Water Treatment. Desalination, 270, 9-22. https://doi.org/10.1016/j.desal.2011.01.010

[57] Ghernaout, D., Benblidia, C. and Khemici, F. (2015) Microalgae Removal from Ghrib Dam (AinDefla, Algeria) Water by Electroflotation Using Stainless Steel Electrodes. Desalination and Water Treatment, 54, 3328-3337.

https://doi.org/10.1080/19443994.2014.907749

[58] Ghernaout, D., Badis, A., Braikia, G., Matâam, N., Fekhar, M., Ghernaout, B. and Boucherit, A. (2017) Enhanced Coagulation for Algae Removal in a Typical Algeria Water Treatment Plant. Environmental Engineering and Management Journal, 16, 2303-2315. https://doi.org/10.30638/eemj.2017.238

[59] Irki, S., Ghernaout, D. and Naceur, M.W. (2017) Decolourization of Methyl Orange (MO) by Electrocoagulation (EC) Using Iron Electrodes under a Magnetic Field (MF). Desalination and Water Treatment, 79, 368-377. https://doi.org/10.5004/dwt.2017.20797

[60] Ghernaout, D. (2018) Magnetic Field Generation in the Water Treatment Perspectives: An Overview. International Journal of Advanced and Applied Sciences, 5, 193-203. https://doi.org/10.21833/ijaas.2018.01.025

[61] Saiba, A., Kourdali, S., Ghernaout, B. and Ghernaout, D. (2010) In Desalination, from 1987 to 2009, the Birth of a New Seawater Pretreatment Process: Electrocoagulation-An Overview. Desalination and Water Treatment, 16, 201-217. https://doi.org/10.5004/dwt.2010.1094

[62] Ghernaout, D. and Ghernaout, B. (2011) On the Controversial Effect of Sodium Sulphate as Supporting Electrolyte on Electrocoagulation Process: A Review. Desalination and Water Treatment, 27, 243-254. https://doi.org/10.5004/dwt.2011.1983

[63] Ghernaout, D., Ghernaout, B. and Naceur, M.W. (2011) Embodying the Chemical Water Treatment in the Green Chemistry: A Review. Desalination, 271, 1-10. https://doi.org/10.1016/j.desal.2011.01.032

[64] Ghernaout, D. and Naceur, M.W. (2011) Ferrate (VI): In Situ Generation and Water Treatment-A Review. Desalination and Water Treatment, 30, 319-332. https://doi.org/10.5004/dwt.2011.2217 
[65] Ghernaout, D., Naceur, M.W. and Ghernaout, B. (2011) A Review of Electrocoagulation as a Promising Coagulation Process for Improved Organic and Inorganic Matters Removal by Electrophoresis and Electroflotation. Desalination and Water Treatment, 28, 287-320. https://doi.org/10.5004/dwt.2011.1493

[66] AitMessaoudene, N., Naceur, M.W., Ghernaout, D., Alghamdi, A. and Aichouni, M. (2018) On the Validation Perspectives of the Proposed Novel Dimensionless Fouling Index. International Journal of Advanced and Applied Sciences, 5, 116-122. https://doi.org/10.21833/ijaas.2018.07.014

[67] Ghernaout, D., Badis, A., Ghernaout, B. and Kellil, A. (2008) Application of Electrocoagulation in Escherichia coli Culture and Two Surface Waters. Desalination, 219, 118-125. https://doi.org/10.1016/j.desal.2007.05.010

[68] Ghernaout, D. (2013) Advanced Oxidation Phenomena in Electrocoagulation Process: A Myth or a Reality? Desalination and Water Treatment, 51, 7536-7554. https://doi.org/10.1080/19443994.2013.792520

[69] Ghernaout, D. (2019) Virus Removal by Electrocoagulation and Electrooxidation: New Findings and Future Trends. Journal of Environmental Science and Allied Research, 85-90.

[70] Rizzo, L., Fiorentino, A. and Anselmo, A. (2013) Advanced Treatment of Urban Wastewater by UV Radiation: Effect on Antibiotics and Antibiotic-Resistant E. coli Strains. Chemosphere, 92, 171-176.

https://doi.org/10.1016/j.chemosphere.2013.03.021

[71] Turolla, A., Cattaneo, M., Marazzi, F., Mezzanotte, V. and Antonelli, M. (2018) Antibiotic Resistant Bacteria in Urban Sewage: Role of Full-Scale Wastewater Treatment Plants on Environmental Spreading. Chemosphere, 191, 761-769. https://doi.org/10.1016/j.chemosphere.2017.10.099

[72] Luukkonen, T., Heyninck, T., Rämö, J. and Lassi, U. (2015) Comparison of Organic Peracids in Wastewater Treatment: Disinfection, Oxidation and Corrosion. Water Research, 85, 275-285. https://doi.org/10.1016/j.watres.2015.08.037

[73] Turolla, A., Sabatino, R., Fontaneto, D., Eckert, E.M., Colinas, N., Corno, G., Citterio, B., Biavasco, F., Antonelli, M., Mauro, A., Mangiaterra, G. and Di Cesare, A. (2017) Defence Strategies and Antibiotic Resistance Gene Abundance in Enterococci under Stress by Exposure to Low Doses of Peracetic Acid. Chemosphere, 185, 480-488. https://doi.org/10.1016/j.chemosphere.2017.07.032

[74] Manoli, K., Sarathy, S., Maffettone, R. and Santoro, D. (2019) Detailed Modeling and Advanced Control for Chemical Disinfection of Secondary Effluent Wastewater by Peracetic Acid. Water Research, 153, 251-262.

https://doi.org/10.1016/j.watres.2019.01.022

[75] Ghernaout, D. and El-Wakil, A. (2017) Requiring Reverse Osmosis Membranes Modifications: An Overview. American Journal of Chemical Engineering, 5, 81-88. https://doi.org/10.11648/j.ajche.20170504.15

[76] Ghernaout, D. (2017) Reverse Osmosis Process Membranes Modeling: A Historical Overview. Journal of Civil, Construction and Environmental Engineering Civil, 2, 112-122.

[77] Ghernaout, D., El-Wakil, A., Alghamdi, A., Elboughdiri, N. and Mahjoubi, A. (2018) Membrane Post-Synthesis Modifications and How It Came about. International Journal of Advanced and Applied Sciences, 5, 60-64. https://doi.org/10.21833/ijaas.2018.02.010

[78] Ghernaout, D. (2019) Brine Recycling: Towards Membrane Processes as the Best Available Technology. Applied Engineering, 3, 71-84. 
[79] Sharma, V.K., Johnson, N., Cizmas, L., McDonald, T.J. and Kim, H. (2016) A Review of the Influence of Treatment Strategies on Antibiotic Resistant Bacteria and Antibiotic Resistance Genes. Chemosphere, 150, 702-714. https://doi.org/10.1016/j.chemosphere.2015.12.084

[80] Ghernaout, D., Alghamdi, A., Touahmia, M., Aichouni, M. and AitMessaoudene, N. (2018) Nanotechnology Phenomena in the Light of the Solar Energy. Journal of Energy, Environmental \& Chemical Engineering, 3, 1-8. https://doi.org/10.11648/j.jeece.20180301.11

[81] Guo, M., Yuan, Q. and Yang, J. (2015) Distinguishing Effects of Ultraviolet Exposure and Chlorination on the Horizontal Transfer of Antibiotic Resistance Genes in Municipal Wastewater. Environmental Science \& Technology, 49, 5771-5778. https://doi.org/10.1021/acs.est.5b00644

[82] McConnell, M.M., Hansen, L.T., Jamieson, R.C., Neudorf, K.D., Yost, C.K. and Tong, A. (2018) Removal of Antibiotic Resistance Genes in Two Tertiary Level Municipal Wastewater Treatment Plants. Science of the Total Environment, 643, 292-300. https://doi.org/10.1016/j.scitotenv.2018.06.212

[83] Ghernaout, D. (2017) Water Reuse (WR): The Ultimate and Vital Solution for Water Supply Issues. International Journal of Sustainable Development Research, 3, 36-46. https://doi.org/10.11648/j.ijsdr.20170304.12

[84] Ghernaout, D., Alshammari, Y., Alghamdi, A., Aichouni, M., Touahmia, M. and AitMessaoudene, N. (2018) Water Reuse: Extenuating Membrane Fouling in Membrane Processes. International Journal of Environmental Chemistry, 2, 1-12. https://doi.org/10.11648/j.ajche.20180602.12

[85] Ghernaout, D., Elboughdiri, N. and Al Arni, S. (2019) Water Reuse (WR): Dares, Restrictions, and Trends. Applied Engineering, 3, 159-170.

[86] Ghernaout, D., Aichouni, M. and Alghamdi, A. (2018) Applying Big Data (BD) in Water Treatment Industry: A New Era of Advance. International Journal of Advanced and Applied Sciences, 5, 89-97. https://doi.org/10.21833/ijaas.2018.03.013

[87] Alshammari, Y., Ghernaout, D., Aichouni, M. and Touahmia, M. (2018) Improving Operational Procedures in Riyadh's (Saudi Arabia) Water Treatment Plants Using Quality Tools. Applied Engineering, 2, 60-71.

[88] Ghernaout, D. (2019) Greening Cold Fusion as an Energy Source for Water Treatment Distillation: A Perspective. American Journal of Quantum Chemistry and Molecular Spectroscopy, 3, 1-5.

[89] Ghernaout, D. (2017) Environmental Principles in the Holy Koran and the Sayings of the Prophet Muhammad. American Journal of Environmental Protection, 6, 75-79. https://doi.org/10.11648/j.ajep.20170603.13

[90] Ghernaout, D., Elboughdiri, N. and Ghareba, S. (2019) Drinking Water Reuse: One-Step Closer to Overpassing the "Yuck Factor". Open Access Library Journal, 6, e5895. https://doi.org/10.4236/oalib.1105895

[91] Al Arni, S., Amous, J. and Ghernaout, D. (2019) On the Perspective of Applying of a New Method for Wastewater Treatment Technology: Modification of the Third Traditional Stage with Two Units, One by Cultivating Microalgae and Another by Solar Vaporization. International Journal of Environmental Sciences \& Natural Resources, 16, Article ID: 555934. https://doi.org/10.19080/IJESNR.2019.16.555934

[92] Ghernaout, D. (2013) The Best Available Technology of Water/Wastewater Treatment and Seawater Desalination: Simulation of the Open Sky Seawater Distillation. Green and Sustainable Chemistry, 3, 68-88. https://doi.org/10.4236/gsc.2013.32012 
[93] Ghernaout, D. (2017) The Holy Koran Revelation: Iron Is a "Sent Down" Metal. American Journal of Environmental Protection, 6, 101-104. https://doi.org/10.11648/j.ajep.20170604.14

[94] Ghernaout, D. (2018) Increasing Trends towards Drinking Water Reclamation from Treated Wastewater. World Journal of Applied Chemistry, 3, 1-9. https://doi.org/10.11648/j.wjac.20180301.11

[95] Ghernaout, D., Alshammari, Y. and Alghamdi, A. (2018) Improving Energetically Operational Procedures in Wastewater Treatment Plants. International Journal of Advanced and Applied Sciences, 5, 64-72. https://doi.org/10.21833/ijaas.2018.09.010

[96] Ghernaout, D. (2019) Reviviscence of Biological Wastewater Treatment: A Review. Applied Engineering, 3, 46-55. 